JOURNAL OF SECURITY AND SUSTAINABILITY ISSUES

ISSN 2029-7017 print/ISSN 2029-7025 online

2019 June Volume 8 Number 4

http://doi.org/10.9770/jssi.2019.8.4(17)

Scopus ${ }^{\circ}$

\title{
METHODICAL APPROACHES TO THE FORMATION OF THE FINANCIAL INSTITUTION SECURITY SYSTEM
}

\author{
Jiafei Guo ${ }^{1}$, Oksana Portna², Volodymyr Rodchenko ${ }^{3}$, Oleksiy Navrotskyy ${ }^{4}$, Jingxu Du ${ }^{5}$ \\ ${ }^{1}$ Luoyang Normal University, Guangwen Rd, Jianxi Qu, Luoyang Shi, Henan Sheng, 471132, China \\ ${ }^{2 * 3,4}$ V. N. Karazin Kharkiv National University, Svobody sq., 4, Kharkiv, 61022, Ukraine \\ ${ }^{5}$ H.S. Skovoroda Kharkiv National Pedagogical University, 29, Alchevskyh (Artema) Str., Kharkiv 61002, Ukraine \\ E-mail: ${ }^{2 *}$ koaduep@gmail.com
}

Received 12 November 2018; accepted 15 April 2019; published 30 June 2019

\begin{abstract}
It is argued that the assessment of the security level of the bank lending activities should be made taking into account the socio-economic interests of all participants in the credit process. The developed methodology of the score assessment of the security level of credit operations of the bank includes not only an analysis of the security status of the credit operations of a particular bank, but also an assessment of the external conditions of its implementation. The process of assessment of the security level of the bank credit operations is implemented in five stages: the development of a system of security indicators for the bank credit operations; formation of the information base, which consists of bank reporting (financial and managerial) and macroeconomic indicators; analysis of security indicators; preparation of the report on the state of security; advising on adjustment of the bank's policy to enhance security of credit operations and prevent the effects of possible threats. The introduction of a methodology for scoring in the practical activities of banks will allow to obtain objective characteristics of the security of credit operations, identify weaknesses, strengthen security measures, improve the bank's credit policy to prevent the effects of possible threats.
\end{abstract}

Keywords: bad loans; security indicators; securitization; loan portfolio; financial level

Reference to this paper should be made as follows: Guo, J,; Portna, O.; Rodchenko, V.; Navrotskyy, O.; Du, J. 2019. Methodical approaches to the formation of the financial institution security system, Journal of Security and Sustainability Issues 8(4): 749-758. http://doi.org/10.9770/jssi.2019.8.4(17)

JEL Classifications: F52, O39

\section{Introduction}

The analysis of the causes and conditions of the formation of a bad credit debt shows that its significant growth occurs during periods of economic, political, and social cataclysms and various crises. It is during such periods that entrepreneurial activity (and not only banking activity) undergoes significant stress, the consequence of which is the violation of its rhythm, failure of business entities to fulfill obligations and the emergence and growth of debts. Under such conditions, an important element of entrepreneurial behaviour must be mutual support and exit out of the situation by joint efforts. Unfortunately, there is no appreciable understanding in the interrelations of banks with their borrowers, depositors, and creditors, their relationships are subject to acute conflicts, in which each party aspires to solve problems independently, including at the expense of other parties. The consequence of this approach is a long-term resolution of problems, the growth of the volume of bad debts, losses, and even loss of business prospects. 


\section{Literature Survey}

The organizational block takes an important place in the system implemented, because it should contain the main organizational principles for the further work of the bank with bad debts (Wang, Y., Hahn, C., \& Sutrave, K. (2016, February); Bondar M., Iershova N. (2015)). Given the diversity of lending relationships between banks with their borrowers, the different bank facilities for servicing loans, and the heterogeneity of borrowers' activities in the market, banks themselves shall determine the relevance of loans to troubled ones, while developing appropriate rules (Wiengarten, F., Fan, D., Lo, C. K., \& Pagell, M. (2017), Lindsay, J. D. (2018); Dalevska, N.; Khobta, V.; Kwilinski, A.; Kravchenko, S. (2019)). Similar situations with borrowers violating their credit obligations in some banks can cause problems, while others do not, so the work of banks with such violations will be different (Austin, J.M., M., Demski, R., Callender, T., Lee, K. K., Hoffman, A., Allen, L., ... \& Pronovost, P. J. (2017), Carpinelli, L., Cascarino, G., Giacomelli, S., \& Vacca, V. (2017); Dobrovolskienė, N.; Tvaronavičienè, M.; Tamošiūnienè, R. (2017)). But under all conditions, banks' approaches to recognition of loans as bad ones must clearly be known to their borrowers. In accordance with the methods of recognition of a loan debt as a bad one, the bank should classify such loans by the methods of dealing with them. As an option, we can offer the following classification:

loans with a value of the risk index up to 0.2 (up to 30 days of delay in accordance with the procedure defined by the Provision on the procedure for the formation and use of reserves by banks for reimbursement of possible losses on active banking operations). The state of service is considered to be high and good. Obviously, the methods of dealing with such loans should be based on compromises in negotiations with the debtors without termination of loan and other agreements;

loans with the value of the risk index up to $0.4-0.5$ (the term of delay is 30 to 90 days). Methods of dealing with such loans may be of an economic nature and involve the suspension or termination of loan agreements; loans with an indicator of risk greater than 0.51 (overdue for more than 90 days). The repayment of loan debts with such a delay should be considered in court.

\section{Methods}

The organization of direct work on the repayment of debts shall be carried out based on the selected classification. Such an organization may provide for actions relay in on external subjects (courts, law enforcement agencies, collectors and other enterprises) or without such support - at the expense of their own forces. In this case one cane recommend the bank to act on its own with respect to debts with a risk of no more than 0.5 or when the size of the bad debt is not more than $10 \%$ of the loan portfolio.

There should be developed common approaches to the use of security forces and the application of appropriate measures to protect the subjects in the process of their credit or other relationships. The common approaches in the common defence system will be built through the creation of appropriate security levels: informational, personnel, financial, and regulatory.

\section{Results}

The information level involves protection of the interests of participants in lending activities through minimization of information threats and counteracting them. A secure information space for the relationships of these participants is created in the formation and use of credit resources by the bank. We recommend to create joint information databases, develop common methods for detection, identification, evaluation, protection and counteraction to disinformation, rumors, discreditation, blackmailing, and informational impact technologies, and coordinate the activities of participants in the field of their information security in fulfilling their obligations.

The personnel level shall be formed through provision of counteraction to any manifestations of unfair and criminal behaviour by personnel of participants of loan activity on the basis of development of uniform methods and criteria of control of behaviour and work of employees involved in the preparation and support of certain operations. 
The financial security level includes:

formation of joint bodies of coordination and management of operations in the concrete relations of participants of credit operations;

the creation of joint working groups of representatives of participants of credit operations for carrying out of corresponding operations; the determination of their functions and the introduction of a single procedure for reporting on the state of their operations, this can be especially effective for operations that are significant in volume or are strategic for the participants in credit operations;

introduction of centralized and independent control of the state and dynamics of operations in an automated mode, with periodic communication of its results to each of the participants in credit operations; formation of tactics of actions of participants of credit activity in case of violation of technology of operations, unforeseen relationship of use (provision) of funds or unfair behaviour of participants.

The regulatory level of security shall be created by introduction of appropriate restrictions and prohibitions both in the technology of operations and in the relations of the participants of credit operations. The regulatory measures exclude actions of participants, which can negatively affect the results of corporate interest in credit operations.

The methods of provision of security should be diverse and aimed at crossing all possible types of threats and areas of their actions: informational, economic, social-personnel, technological, technical, and legal. Moreover, there should not be any specialization of methods for participants in credit operations. The latter must possess a complete arsenal of such methods, applying them within the limits of their functions assigned to them in the relevant relationships (Dang, T. V., Gorton, G., Holmström, B., \& Ordonez, G. (2017); Faridi, M.F.; Sulphey, M. M. (2019)). At the same time, the need for application or methodology for the use of security methods must be coordinated with all stakeholders and be motivated by the danger of threats and be adequate to the situation.

That is, the credit activity security system should be focused on ensuring the development of credit relations in accordance with the previously agreed and approved scenario and to prevent its violations. To this end, a significant part of security measures should focus on creation of favorable conditions for the establishment and development of relationships. An important place in this should be devoted to building a scenario for the development of a specific transaction and the relationships of its subjects, identification the most vulnerable their technologies and stages, and formation of possible options for using the security system capabilities to counter threats and protection against them. In all circumstances, any changes in the technology of operations and the relationships of participants in lending activities should be as predictable and controlled as possible.

The function of legal priority ensures that all security measures shall be carried out in accordance with the standards developed jointly by all participants in credit operations. The basis of such rules should be formed by appropriate legal framework for the relationship of the named participants, including with regard to the regulation of measures of protection of their interests (Bauer, S., \& Bernroider, E. W. (2017); Limba T., Agafonov K., Paukštė L., Damkus, M., Plèta T. (2017); Masood, O., Tvaronavičienė, M., Javaria, K. (2019); Chunikhin, S.A., Kuzmin, E.A., Pushkareva, L.V. (2019); Ashraf, M., Masood, O., Tvaronavičienė, M., Aktan, B., GarškaitėMilvydienė, K., Lace, N. (2019); Masood, O., Aktan, B,, Gavurová, B., Fakhry, B., Tvaronavičienė, M., Martinkuté-Kaulienè, R. (2017)). That is, ensuring the security of credit operations should be accompanied by relevant local rules that extend its impact on all its participants in the field of relations caused by the formation or use of credit resources.

As you can see, an information base that is used when creating a system of security indicators of insurance activities is formed on the basis of macroeconomic indicators and indicators of credit operations. The indicator system is composed of indicators that reflect the level of financial and economic stability, adaptation, countering threats, continuous development and efficiency of use of resources (Mironova, N., Dimitrov, N., Tsenkov, Y. (2019); Nikolov K., N. Mironova. (2019)). 
At the first stage of the determination of an integrated security assessment of the bank credit operations, the selection of a set of indicators shall be carried out in order to assess the status of functional components of security, which ensures the adoption of managerial decisions regarding the analysis, prevention and neutralization of real and potential threats to the security of credit operations of the banks.

The development of an effective system of indicators of the security of credit operations of banks is a complicated methodological problem, since their quantity and quality should be sufficient in order to timely and adequately signal about the emergence and development of destabilizing trends in the bank, while not burdening the security system created for error-free and operational responding to possible threats. So, the list of indicators should ensure, on the one hand, the implementation of the most powerful and reliable analysis, and, on the other hand, the opportunity to quickly obtain information for their calculations. In this case, it is necessary to exclude those indicators that are not subject to calculation or duplicate each other (Drobyazko, S. (2018a), Drobyazko, S. (2018b)). That is why it is expedient to calculate the security indicators of the bank credit operations based on the data of public accounting statements of banks, which will enable to quickly determine the security level of credit operations and to conduct its rating in a competitive environment.

The author selected four criteria to help assess the security of credit operations of banks, as shown in Table 1 .

Table 1. Criteria and security indicators of bank credit operations

\begin{tabular}{|l|l|}
\hline \multicolumn{1}{|c|}{$\begin{array}{c}\text { Criteria for the security } \\
\text { of banks' lending activities }\end{array}$} & \multicolumn{1}{c|}{ Security indicators of banks' lending activities } \\
\hline $\begin{array}{l}\text { 1. Criterion of efficiency of formation } \\
\text { and use of banking resources }\end{array}$ & $\begin{array}{l}\text { the rate of use of paid resources; the rate of use of aggregate liabilities; the rate of use of } \\
\text { deposits. }\end{array}$ \\
\hline 2. Risk Criterion & $\begin{array}{l}\text { ratio of loans to liabilities; level of credit portfolio problematicity; ratio of capital to } \\
\text { loan; ratio of bank reserves for coverage of losses. }\end{array}$ \\
\hline $\begin{array}{l}\text { 3. The criterion of efficiency of the } \\
\text { bank operation }\end{array}$ & profitability of the attracted resources; profitability of assets; profitability of credit operations \\
\hline $\begin{array}{l}\text { 4. The criterion for the bank security } \\
\text { level }\end{array}$ & $\begin{array}{l}\text { the norm of instant liquidity; the ratio of received and issued inter-bank loans; multiplier of a } \\
\text { capital. }\end{array}$ \\
\hline
\end{tabular}

The formation of the credit resources, as well as their use is related to the functions of the credit and, first of all, with redistribution function. The redistribution process are connected to the accumulation of credit resources, on the one hand, and placement them in loans - on the other hand. The strengthening of the resources base promotes the increase in the capabilities of banks to meet the current and investment needs of the economy subjects and households in additional financial resources. Each operation of banks, which implementation is related to the change in the volume and composition of its resources, brings profit or expenses. The criterion of the effectiveness of the formation and use of bank resources allows to performe an adequate analysis of the real situation in the bank and formulate ways to improve the security of credit operations of banks.

We propose to evaluate the efficiency of the formation and use of bank resources using the rate of utilization of paid resources, coefficient of use of aggregate liabilities, coefficient of use of deposits and ratio of loans and liabilities.

The risk criterion is based on the features included in the risk classification of the bank. The value of assessment of the risk criterion is that it is possible to simulate banking activity on its basis and carry out a comprehensive search of internal reserves in order to increase the effectiveness of the security of the bank credit operations. The approach proposed by the author is aimed not at the transfer of all types of bank risks, but the creation of a certain system of bank risk indicators, which allows banks not to omit their individual varieties in determining the total size of risks in their activities. We propose that such indicators include the ratio of capital to issued the loans issued, level of bad loans and coefficient of provisions for losses at the expense of the banks reserves.

The analysis makes it possible to determine the trends and regularities of the activity, to assess the impact of 
external and internal factors on the functioning of the banks; scientifically substantiate the planning of further work and control over its implementation; determine the development potential and reserves for improvement of its efficiency. The effectiveness of the bank should be determined through the calculation of profitability of attracted resources, assets and credit operations.

Under the criterion of the bank security level one should understand the stability of the financial and economic development of the bank. The ability to quickly settle under current liabilities creates prerequisites for the stable operation of the bank. The slightest signs of a failure by the banks to fulfill their obligations can cause panic among the clients, which in turn can lead to bankruptcy of the commercial bank. The level of bad loans in the loan portfolio is capable of signalling of the decline in financial security at early stages. The level of aggressiveness of the credit policy of the bank has a direct impact on the level of its protection and financial security. Recently, the importance of controlling the currency position has increased significantly (Stattev, S.V., Boiarchuk, A., Portna, O., Dielini, M., Pylypiak, O. (2019); Koev, S.R, Moroz, I., Mushynska, N., Kovin'ko, O., Kovalchuk, S. (2019)).

In addition to the specified indicators, it is mandatory to take into account the external conditions of the credit activity and their impact on the security of credit relations. In a market economy, the bank is an open system, the activity of which is the interaction of internal and external environment. These two components are constantly in tight interconnection. Depending on the force of influence of factors of each environment, one of them is dominant over the other and affects its functioning.

By systematizing and singling out certain factors, one must take into account that the security system of the credit operations of banks is formed simultaneously under the influence of a whole complex of economic processes and phenomena. Factors do not operate in isolation but systemically.

The determination of the main characteristics of the values of indicators used in the analysis of the level of security shall be performed at the second stage.

For indicators of financial statements of banks, the economically feasible minimum and maximum values of the indicators or their lower and upper limits shall be determined, macroeconomic indicators shall be investigated in the dynamics, that is, their change in a certain direction will indicate a decrease or strengthening of the level of security of the bank credit operations.

Exceptions here are macroeconomic indicators that do not have threshold values, so we will evaluate them in dynamics, that is, the change in such indicators in a certain direction should be regarded as a positive or negative feature.

The third stage is an expert assessment, in which the weighting coefficients are assigned to the calculated indicators. In the conditions of considerable uncertainty of the environment, it is proposed to use one of the traditional heuristic methods to solve the problem - the method of expert evaluations.

The presented methodology for assessment of the security of credit operations of the bank takes into account two components:

1) external conditions of bank credit operations, that is, assessment of macroeconomic indicators of security of the bank credit operation (the maximum sum of scores is 35);

2) the state of security of credit operations of a particular bank, which is evaluated using two components, namely assessment of the performance of the functions of the security system of credit operations (estimated condition of the three components) and assessment of security indicators of credit operations of banks (the maximum sum of scores is 95) (Figure 1). 




Figure 1. An assessment of the security of bank credit operations

The assessment of the banks' credit operations shall be carried out based on the determined indicators of the security of credit operations of banks.

1-5 points are assigned to each of indicators: 1 - the minimum value, 5 - the maximum value. If the bank does not meet the recommended or normative values - 1 point, the average value - 3 points, meets normative or recommended values -5 points. The total maximum amount of points the bank receives for this block is 65 points. The macro indicator of security of the bank credit operations are evaluated in the same way.

The assessment of the security of the bank credit operations shall be carried out using the analysis of the degree of execution of functions, which should be executed by this system, giving 10 scores for the implementation of each element of the security system of bank credit operations.

1. The element "Rules of Conduct" assesses the information-analytical and consultative-organizational function and the function of mutual support and control (the maximum amount of points - 10).

2. The element "Technology of operations (relationships)" evaluates the individual-situational and adaptive functions, as well as the functions of operational autonomy and management (the maximum amount of points - 10).

3. The element "Means of Protection" evaluates corporate security and integrated approach, legal priority and planned function (maximum sum of points - 10).

That is, the maximum score of estimation of functions of the security system of credit operations is 30 points.

On the basis of the obtained sum of scores for assessment of the functions of the security system of credit operations and assessment the security performance of credit operations of banks (internal and external), a conclusion can be made on the level of security of credit operations of the bank (Table 2).

Table 2. An assessment of the security of bank credit operations

\begin{tabular}{|c|c|c|c|c|}
\hline $\begin{array}{c}\text { The number of points } \\
\text { received by the bank }\end{array}$ & 20 to 40 points & 41 to 60 points & 61 to 100 points & 101 to 130 points \\
\hline $\begin{array}{c}\text { The level of security of credit } \\
\text { operations of the Bank of Ukraine }\end{array}$ & critical & low & medium & high \\
\hline
\end{tabular}

The fourth stage of the assessment is to provide recommendations for changing or maintaining a bank's credit policy based on the obtained quantitative assessment.

For a visual assessment of the security performance of credit operations, experts prepare a "Report on the assessment of credit operations of the bank": the name of the bank, which assesses security; indication of the period for which the assessment is made; formation of a system of indicators for analysis; provision of the results of their calculation and determination of the number of points for each indicator in tabular form; determination of the level of security assessment; advising on changing the bank's credit policy. 
The application of the proposed security system of credit operations of the bank enables to generate security measures, rules of conduct and technology of conduction of operations at any stage of credit operations. Given the fact that the use of credit resources is performed mainly in the form of credit operations and the fact that the latters in their development go through three stages (preparation of the transaction, its maintenance (monitoring) and repayment of credit funds), each of them will comply with their security measures, rules of conduct and the technology of the relationship (Table 3).

Table 3. The security system at each stage of the bank's credit operations

\begin{tabular}{|l|l|}
\hline \multicolumn{1}{|c|}{ Stages of a credit operation } & \multicolumn{1}{c|}{ Contents of the security system of credit operations of the bank } \\
\hline 1. Preparation of the operation & formation of safe conditions for conduction of a credit operation \\
\hline 2. Monitoring & timely detection of signs that may indicate a violation of the terms of a credit operation \\
\hline 3. Return of funds & $\begin{array}{l}\text { taking measures for the most complete fulfillment of obligations by each participant of a } \\
\text { credit operation. }\end{array}$ \\
\hline
\end{tabular}

Considering credit operations as a complex, multi-stage system of its relations with the participants of such operations and paying considerable attention to each of their stages, one can distinguish one of them, which is the most complicated, labor-intensive and costly for the bank. It is a question of the bank's work on repayment of credit debt, which due for one reason or another was not returned by borrowers in accordance with their contractual obligations. Unfortunately, today such work is a constant attribute of credit operations of domestic banks.

The mechanism for managing the process of returning bad loans is ensured through the creation of a corresponding coordination group in the bank consisting of representatives of the bank, debtor and the entities involved in the recovery of debts.

The main instrument of influence on the debt situation will be negotiations and agreements, information measures of support of the process of repayment of debts, and legal measures.

An important place in the proposed system is given to the structural unit, through which forces and means the direct work on the return of debts is carried out. At present, a significant part of banks have subdivisions in their structure that are dealing with bad debts. Without going into a detailed analysis of their work, taking into account only significant amounts of bad debts that did not change significantly, and sometimes even grow, one can make a conclusion on expediency of their existence. In addition, these units perform work that could be successfully performed by other units involved in lending, such as: credit, security, legal, and risk units. In addition, the existence of units dealing with bad debts, as a rule, does not depend on the results of their work, and their methods, as a rule, are patterned.

\section{Discussion}

In addition, banks bear additional costs for the maintenance of such units. Taking into account that modern business activity (including banking) is accompanied by large volumes of bad debts, the services on their return are began to be offered more and more often in the market. The emergence of such proposals has led to the formation of a new type of activities - work on the repayment of debts. Specific conditions of the present tiem, in which banks were, makes such activity quite relevant. Proceeding from this and in order to make bank deal with bad credit debts more professionally, banks are proposed to create their own collection companies. The establishment of such enterprises could involve not only one but a few banks. When dealing with the debts of banks, such enterprises could simultaneously provide services to other entities, thereby enhancing their professional skills and minimizing their maintenance costs.

The urgency of the bad loan debt securitization is caused by the large capacity of the market of such debts and significant valid credit transactions that enables to form an additional segment of the stock market and positive prospects of its development (Provan, D. J., Dekker, S. W., \& Rae, A. J. (2017), Sexton, J. B. \& amp; Klinect, J. R. (2017)). The main advantages of securitization of bad loan debts are: the possibility of redistribution of 
the risk of a large concentration of bad loans in banks, providing banks with additional sources of financial resources, release bank balances from negative assets, improvement of their credit rating, improvement of banks' liquidity, creation of a secondary market for such assets, which are the loans.

An important point in this approach is that the securitization of bad credit debts does not seriously impair the interests of credit relations subjects, enabling them to resolve all issues without conflict.

\section{Conclusions}

The security system proposed forms the relevant functions in each of its components that are implemented in various areas of relations: economic, informational, legal, and organizational ones, supporting them at a given level and avoiding contradictions or conflicts. The security system capabilities are formed from the capabilities of each of the participants in credit operations, to whom mutually agreed powers on protection of the security object are delegated.

As a result of the use of the methodology for assessment of the security of credit operations of banks, one can determine whether there are internal forces and resources in the bank to implement the available capabilities, to which extent the bank is prepared to withstand the negative impact of the external environment, and, importantly, this analysis will help to identify internal deficiencies that need to be addressed and will provide a high level of security of the bank credit operations.

The use of the considered indicators in assessment of the level of security of lending activities of the bank allows it to correctly form its investment and credit policy and make sound management decisions for determination of the optimal structure of capital.

The introduction of the developed algorithm for security analysis of credit operations of the bank on the basis of calculation of the level of functional components of the security of credit operations of the bank will significantly increase the efficiency of the entire bank management system, since it will enable continuous monitoring and evaluation of the state of the security, timely detection of threats and risks, and make effective decisions to minimize them.

The complex nature of the proposals aimed at protection of the interests of credit institutions in the procedure for the recovery of bad debts will not allow to break the relationship between the bank and their clients and will provide better repayment of debts through the application of various methods of working with loan debts. The accent is transferred from the debtor to the debt, and the result is achieved through the joint work of the debtor and the bank.

Typically, the task of managing risks in industrial organizations is assigned to special structural units. In the event that the infrastructure of the industrial organization not provides such a unit, the management may decide to engage regular risk management specialists or external consultants. However, as experience shows, quite often the risk management functions are imposed on other structural units. Typically, these tasks can be performed by the internal audit department, controlling service, and forecasting analytical unit. In this situation, threats are diagnosed in a timely manner, and their consequences are eliminated promptly, which protects the commodity producer from the probable significant losses.

It was substantiated that risk situations are accompanied by an urgent need to choose between different variants, a polar understanding of a certain magnitude of risk by theoreticians and practitioners as a result of differences between psychological and ethical and value systems and principles. This determines the subjectivity of the vision of this category. At the same time, the risk is an objective factor, due to the fact that it is inherent in most of the existing production and economic operations, and functions not being based on the will or consciousness of the individual, and neglect or recognition of its existence by an individual. So, one can agree that the risk itself has both a subjective and objective nature. 
In the course of the study, it was substantiated that socio-economic, organizational and legal factors influence the formation of economic security of an economic entity. Any industrial organization is characterized by certain features in the area of legal relations and the establishment of its own business security system. In view of the imperfection of the current legislation, as well as the level of scientific and practical experience in substantiation and creation of an effective system of economic protection of the manufacturer, it is advisable to draw attention to the achievements of the international community in this area.

Taking into account world experience it can be stated that in developed countries, as a rule, there is a coexistence of two basic systems of formation of economic protection of manufacturers: the systems of protection at the state level, which are responsible for national security, with the spread of their influence on state and private business entities in the plane of the current normative field; private entities that form their own economic security services or use detective-security agencies develop their own systems of necessary mode of confidentiality and security. Only the combination of the capabilities of both systems can guarantee the economic security of business interests, in particular, and in general the interests of the state, by ensuring business stability, preventing the likelihood of bankruptcy, compensating for losses caused by natural disasters or unfair competition, industrial espionage or other illegal actions.

\section{References}

Ashraf, M., Masood, O., Tvaronavičienė, M., Aktan, B., Garškaitė-Milvydienė, K., Lace, N. (2019). Factors Affecting Development Patterns: Econometric Investigation of Japan Equity Market. Economic Research-Ekonomska Istraživanja, 32(1), 440-453, https://doi. org/10.1080/1331677X.2018.1551147

Austin, J. M., Demski, R., Callender, T., Lee, K. K., Hoffman, A., Allen, L., ... \& Pronovost, P. J. (2017). From board to bedside: how the application of financial structures to security and quality can drive accountability in a large health care system. The Joint Commission Journal on Quality and Patient Security, 43(4), 166-175. URL: https://www.sciencedirect.com/science/article/abs/pii/ S1553725017300065

Bauer, S., \& Bernroider, E. W. (2017). From information security awareness to reasoned compliant action: analyzing information security policy compliance in a large banking organization. ACM SIGMIS Database: the DATABASE for Advances in Information Systems, 48(3), 44-68. URL: https://dl.acm.org/citation.cfm?id=3130519

Bondar M., Iershova N. (2015). Strategic management object as an object of scientific research. Baltic Journal of Economic Studies, 1(1), 47-54. http://dx.doi.org/10.30525/2256-0742/2015-1-1-47-54

Carpinelli, L., Cascarino, G., Giacomelli, S., \& Vacca, V. (2017). The management of non-performing loans: a survey among the main Italian banks. Politica economica, 33(2), 157-188. URL: https://www.rivisteweb.it/doi/10.1429/87182

Chunikhin, S.A., Kuzmin, E.A., Pushkareva, L.V. (2019). Studying the banking industry's stability through market concentration indices. Entrepreneurship and Sustainability Issues, 6(4), 1663-1679. http://doi.org/10.9770/jesi.2019.6.4(8)

Dalevska, N., Khobta, V., Kwilinski, A., Kravchenko, S. (2019). A model for estimating social and economic indicators of sustainable development. Entrepreneurship and Sustainability Issues, 6(4), 1839-1860. http://doi.org/10.9770/jesi.2019.6.4(21)

Dang, T. V., Gorton, G., Holmström, B., \& Ordonez, G. (2017). Banks as secret keepers. American Economic Review, 107(4), $1005-29$. https://www.aeaweb.org/articles?id=10.1257/aer.20140782

Dobrovolskienè, N., Tvaronavičienè, M., Tamošiūnienė, R. (2017). Tackling projects on sustainability: a Lithuanian case study. Entrepreneurship and Sustainability Issues, 4(4), 477-488. http://doi.org/10.9770/jesi.2017.4.4(6)

Drobyazko, S. (2018a). Accounting management of enterprises' own of in the conditions of legislative changes. Economics and Finance, 10,4-11.http://ecofin.at.ua/maket_ehkonomika_i_finansy_06_2018.pdf

Drobyazko, S. (2018b). Features of tourism services accounting structuring in the information-oriented society. Economics and Finance, 6, 44-49. http://ecofin.at.ua/maket_ehkonomika_i_finansy_10_2018.pdf

Faridi, M.F., Sulphey, M. M. (2019). Food security as a prelude to sustainability: a case study in the agricultural sector, its impacts on the Al Kharj community in The Kingdom of Saudi Arabia. Entrepreneurship and Sustainability Issues, 6(3), 1336-1345. https://doi. org/10.9770/jssi.2019.6.3(34)

Koev, S.R, Moroz, I., Mushynska, N., Kovin'ko, O., Kovalchuk, S. (2019). Features of Building a Managerial Career Based on Entrepreneurship 
Education. Journal of Entrepreneurship Education, Volume 22, Special Issue 1 (Title: Entrepreneurship: Investment and Innovation). https:// www.abacademies.org/articles/features-of-building-a-managerial-career-based-on-entrepreneurship-education-8050.html

Limba T., Agafonov K., Paukštė L., Damkus, M., Plèta T. (2017). Peculiarities of cyber security management in the process of internet voting implementation. Entrepreneurship and Sustainability Issues, 5(2), 368-402. http://doi.org/10.9770/jesi.2017.5.2(15)

Lindsay, J. D. (2018). U.S. Patent No. 9,959,694. Washington, DC: U.S. Patent and Trademark Office. URL: https://patents.google.com/ patent/US9959694B2/en

Masood, O., Aktan, B,, Gavurová, B., Fakhry, B., Tvaronavičienė, M., Martinkute-Kaulienė, R. (2017). The impact of regime-switching behaviour of price volatility on efficiency of the US sovereign debt market. Economic Research-Ekonomska Istraživanja, 30:1, 1865$1881 \mathrm{http}: / /$ dx.doi.org/10.1080/1331677X.2017.1394896

Masood, O., Tvaronavičienè, M., Javaria, K. (2019). Impact of oil prices on stock return: evidence from G7 countries. Insights into Regional Developmen, 1(2), 129-137. https://doi.org/10.9770/ird.2019.1.2(4)

Mironova, N., Dimitrov, N., Tsenkov, Y. (2019). Entrepreneurial Model of Local Innovation Development in the European Union Economy. Journal of Entrepreneurship Education. Volume 22, Special Issue 1 (Title: Entrepreneurship: Investment and Innovation). https://www. abacademies.org/articles/entrepreneurial-model-of-local-innovation-development-in-the-european-union-economy-8051.html

Nikolov K., N. Mironova. (2019). Creation of Smart Public Relations in the Security Organizations. Journal L`Association 1901 "SEPIKE", Ausgabe 1(22), 61-67, ISSN: 2372-7438, 2196-9531

Provan, D. J., Dekker, S. W., \& Rae, A. J. (2017). Bureaucracy, influence and beliefs: A literature review of the factors shaping the role of a security professional. Security science, 98, 98-112. https://www.sciencedirect.com/science/article/pii/S0925753517301157

Sexton, J. B., \& Klinect, J. R. (2017). The link between security attitudes and observed performance in flight operations. In Human Error in Aviation (pp. 513-518). Routledge. https://www.taylorfrancis.com/books/e/9781351563475/chapters/10.4324/9781315092898-25

Stattev, S.V., Boiarchuk, A., Portna, O., Dielini, M., Pylypiak, O. (2019). Formation of a System of Anti-Crisis Entrepreneurship of Services Companies. Journal of Entrepreneurship Education. Volume 22, Special Issue 1 (Title: Entrepreneurship: Investment and Innovation). https://www.abacademies.org/special-issues/volume-22-special-issue-1-title-entrepreneurship-investment-andinnovation.html

Wang, Y., Hahn, C., \& Sutrave, K. (2016, February). Mobile payment security, threats, and challenges. In Mobile and Secure Services (MobiSecServ), 2016 Second International Conference on (pp. 1-5). IEEE. https://ieeexplore.iee.org/abstract/document/7440226

Wiengarten, F., Fan, D., Lo, C. K., \& Pagell, M. (2017). The differing impacts of operational and financial slack on occupational security in varying market conditions. Journal of operations management, 52, 30-45. https://www.sciencedirect.com/science/article/abs/pii/ S0272696316300961

Short biographical note about the contributors at the end of the article:

Jiafei GUO, Philosophy Doctor (Economic), Luoyang Normal University, Henan Sheng, China

ORCID ID: 0000-0001-8199-7356

Oksana PORTNA, Doctor of Sciences (Economic), Associate Professor, V. N. Karazin Kharkiv National University, Ukraine ORCID ID: orcid.org/0000-0002-8803-4605

Volodymyr RODCHENKO, Doctor of Sciences (Economic), Professor, V. N. Karazin Kharkiv National University, Ukraine ORCID ID: orcid.org/0000-0003-0298-4747

Oleksiy NAVROTSKYY, Doctor of Sciences (Law), V. N. Karazin Kharkiv National University, Ukraine ORCID: ID: orcid.org/0000-0003-0961-3164

Jingxu DU, H.S. Skovoroda Kharkiv National Pedagogical University, Ukraine

ORCID ID: https://orcid.org/0000-0002-7337-5167

This work is licensed under the Creative Commons Attribution International License (CC BY).

http://creativecommons.org/licenses/by/4.0/ 